Acta Technologica Agriculturae 1

Nitra, Slovaca Universitas Agriculturae Nitriae, 2019, pp. 22-30

\title{
MORTALITY OF BROILER CHICKENS DURING SUMMER FATTENING PERIODS AFFECTED BY MICROCLIMATIC CONDITIONS
}

\author{
Veronika ŠRANKOVÁ ${ }^{1 *}$, Jana LENDELOVÁ ${ }^{\prime}$ Štefan MIHINA', Miroslav ŽITŇÁK' , Gregorz Nawalany² \\ ${ }^{1}$ Slovak University of Agriculture in Nitra, Slovak Republic \\ ${ }^{2}$ University of Agriculture in Krakow, Poland
}

\begin{abstract}
Mortality of chickens during two summer fattening periods $L 1$ and $L 2$ in commonly used halls for chicken fattening in Slovakia have been evaluated in this paper. Effect of microclimatic conditions in housing area on recorded mortality has been analysed. Mortality was assessed in six halls, microclimate parameters and surface temperatures were continually measured only in one of the middle halls. It was documented that high mortality occurred during summer in the last phase (P3) of fattening period due to sudden hot weather waves. Daily mortality rate varied up to 447 birds in evaluated hall 3 . During the last third of both fattening periods, it was significantly higher than during the first two phases $\left(P_{L 1}=0.0036 ; P_{L 2}=1.4 \cdot 10^{-6}\right)$. Differences among halls were insignificant $\left(P_{L 1}=0.614 ; P_{L 2}=0.413\right)$. In $L 1$, average daily temperatures went beyond the recommended temperatures from $21^{\text {st }}$ to $31^{\text {st }}$ day. During $L 2$, it was from $29^{\text {th }}$ to $31^{\text {st }}$ day and from $36^{\text {th }}$ to $38^{\text {th }}$. The extra high mortality occurred in $L 1$ on $31^{\text {st }}$ day ( 447 birds) and during $L 2$ on $36^{\text {th }}$ day ( 88 birds), $37^{\text {th }}$ day ( 96 birds) and $38^{\text {th }}$ day (155 birds). High differential temperatures have been recorded and uninterrupted time periods ( 6 hours or more) with temperature higher than $30^{\circ} \mathrm{C}$ and/or the relative humidity $(R H)$ exceeding $70 \%$ were occurred during these days. In order to eliminate effect of sudden hot weather waves, modern digitally controlled microclimate regulation technologies (heat pumps, floor cooling, etc.) can be used, supported by data obtained from detailed microclimate analysis documented in this paper.
\end{abstract}

Keywords: broiler chicken housing; mortality; microclimate

With a changing climate, there is an increasing trend in occurrence of extreme climatic events such as heat waves that cause losses in livestock production and negatively affect animal welfare (Lin et al., 2006). High outdoor temperatures burden internal climate in many poultry houses (Sax et al., 2012). They cause heat stress to animals, which has a negative effect on their daily gain in weight, feed intake, growth rate, physiological mechanism and health status (Li et al., 2000). Even one day of high heat causes heat shock and thus high broiler mortality (>1.2\%) (Vale et al., 2010). Breeding conditions in poultry houses depend on physical (temperature, relative humidity, lighting, ventilation and dust), chemical factors (air composition such as ammonia, carbon dioxide and oxygen) (Kocaman et al., 2005; Liang et al., 2005; Nawalany, 2012), and stocking density (Sorensen et al., 2000; Algers and Berg, 2001; Hall, 2001; Bod'o and Gálik, 2018). Lower mortality and better production parameters were observed in housing with effective environmental quality control, water mist and forced ventilation or floor heating/cooling system (Okelo et al., 2003; Nawalany et al., 2010). Cordeiro et al. (2011) report that one-day-old chickens have difficulty in maintaining body heat because their thermoregulatory capacity is not well developed. Therefore, young chickens ( 1 to 14 days old) must be kept in an environment with temperature of approx. $35^{\circ} \mathrm{C}$ to maintain a constant body temperature. Cooper and Washburn (1998) stated that as chickens grow, they are more vulnerable to high temperatures. According to Thiele and Pottgüter (2008), optimal temperature for adult chickens is $18{ }^{\circ} \mathrm{C}$. Air temperature exceeding $32{ }^{\circ} \mathrm{C}$ is considered stressful. Optimal relative humidity in the poultry houses should range between $50 \%$ and $70 \%$. If relative humidity falls below the recommended levels, mortality may increase and respiratory diseases may occur in some cases (Czarick and Farichild, 2012). If relative humidity rises above $70 \%$, excessive body heat is drained poorly and air quality is rapidly decreased (Xin et al., 2001; Genc and Portier, 2003; Bansal et al., 2012). In regards to temperature and relative humidity, animal welfare is expressed by the temperature and humidity index $(T H I)$ proposed by Chepete et al. (2005). It is calculated on the basis of dry and wet temperature. Multiple authors (Heier et al., 2002; Yassin et al., 2009; Chou et al., 2004) studied mortality during the first week of fattening in relation to the next weeks in order to propose improvements of chicken welfare. According to the experience from farms at which the measurements were performed, it is known that mortality is significantly affected by extreme climatic changes in summer by sudden warming, causing a critical 
heat load especially during the last days of fattening. That is reason why research proposed is dedicated to this issue.

Aim of the paper is to evaluate the mortality of chickens during the two summer fattening periods and to find out how microclimatic conditions in housing area affect it. Following hypotheses were established:

H1: Increased mortality of broiler chickens occurs at the beginning of a fattening period and also in summer at the end of it, when it is caused by increased temperature and/or relative air humidity.

$\mathrm{H} 2$ : Increased mortality of broiler chickens at the end of the summer fattening period is the most properly characterized by the average daily air temperature and relative humidity.

H3: Differential temperature (defined by the difference between actual air temperature and required air temperature) better characterizes heat load of the chickens during the last phase of fattening than the average daily temperature.

H4: For accurate identification of the influence of temperature and relative humidity changes on mortality, their daily averages are not sufficient. Their actual values should be evaluated in more detail - at least at hourly intervals.

$\mathrm{H} 5$ : Floor temperature is lower than air temperature throughout overall fattening.

\section{Material and methods}

Measurements were carried out at farm for chicken broilers with 6 identical halls in Southwest Slovakia. The halls are placed side by side with the same pitch of $17 \mathrm{~m}$ between them. Chickens (ROSS 308) were housed into all broiler houses at the same time. Housing area of each hall is 10.5 meters wide and 100.6 meters long, with a total maximum capacity of 20,000 broilers. However, there are only as many birds in the hall so that they do not weigh more than $30 \mathrm{~kg}$ per 1 square meter at the end of fattening period. Walls and roof of halls are made as sandwich panels with thermal insulation of $50 \mathrm{~mm}$ thickness. Concrete floor of $150 \mathrm{~mm}$ thickness is laid on a gravel substrate. The halls are disinfected before each fattening period and floor is subsequently covered with a 100-150 mm high chopped straw bed. The air is supplied to the hall by adjustable flaps with dimensions of $530 \times 260 \mathrm{~mm}$ located along both longitudinal sides of the hall $(2 \times 44$ pcs.). The exchange of air in the breeding area is ensured by five ceiling suction fans with a diameter of $645 \mathrm{~mm}$ and a capacity of 13,600 cubic meters per hour. Ventilation in the hall is controlled by the gradual activation of the ceiling fans until the desired internal state of environment is achieved. During the summer season, 3 exhaust fans are also used, each with a diameter of $1,400 \mathrm{~mm}$ and a capacity of 36,000 cubic meters per hour. Ventilation is automatically regulated on the basis of temperature and humidity conditions in the housing area. Assessment of mortality and microclimatic parameters took place during two periods in May-June 2016 ( $L 1$ period) and May-June 2017 ( $L 2$ period). Fattening period length was 39 days in both cases. Mortality was assessed in all six halls, microclimate parameters and surface temperatures were continually measured only in one of the middle halls (Hall 3). Mortality was recorded daily. Indoor and outdoor microclimate parameters - air temperature and relative humidity were continuously measured throughout the whole fattening periods. Data were recorded at 10 minute intervals via the COMET S 3121 datalogger. On the basis of measured data, average daily values of temperature and relative humidity were calculated. Recommended values for the chickens (Ross 308, 2018) were used as a benchmark. Since the recommended values are set at 3 day intervals, we have set the temperature values at four humidity levels by regression and interpolation for the other days from day 1 to day 27 (Fig. 1).

This allowed to establish daily so-called "Differential temperature", i.e. values that exceeded the recommended temperatures at corresponding relative humidity values. At critical periods of higher mortality, microclimate parameters were analysed at hourly intervals. We have determined the limits of the air temperature $\left(T_{a i}\right)$ and the relative air humidity of the given type of housing in Slovak climate zone and calculated the length of exposure of $T_{a i} \geq 30{ }^{\circ} \mathrm{C}$ and $R H \geq 70 \%$. In order to assess the temperature-humidity status of the environment, THI was calculated. Since

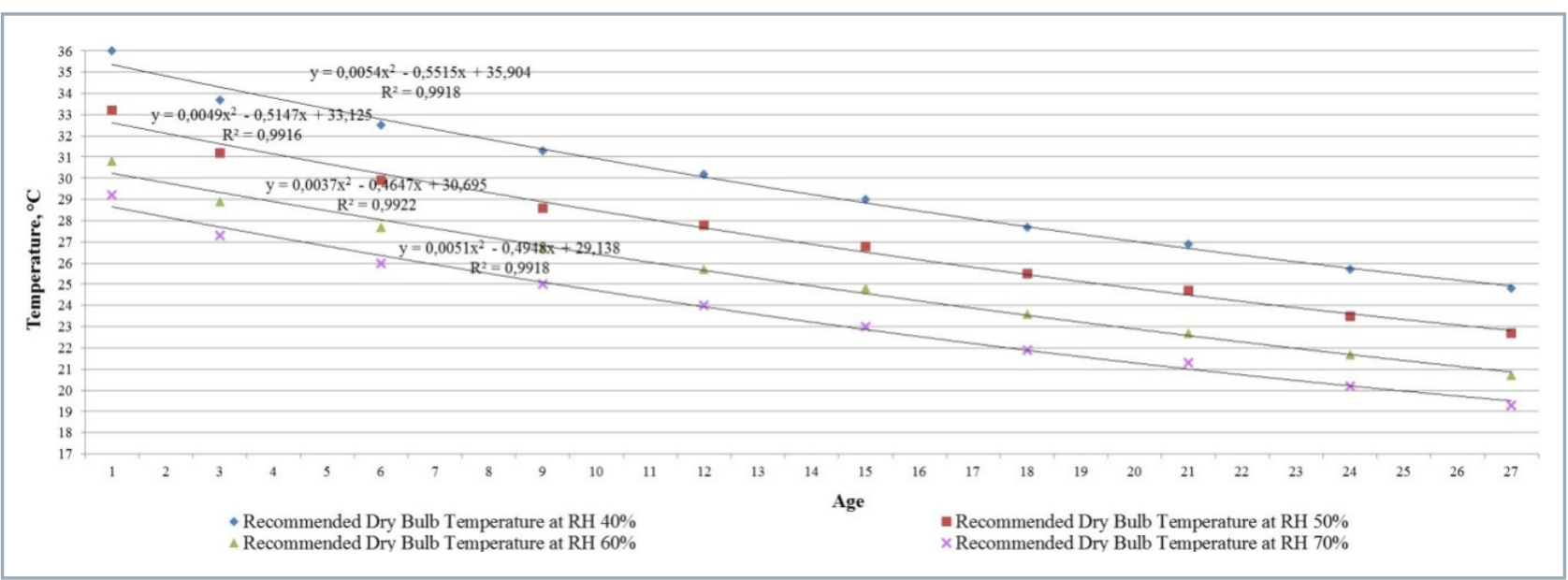

Fig. 1 Recommended air temperature values for 4 relative humidity levels (Ross, 2018) and their adjustment by regression for climate data processing for each day of fattening period 
interpretation boundaries of it are not specified for Slovak climatic conditions, method of Chepete et al. (2005) was utilized as follows:

$$
T H I_{5-6 w k}=0.71 T_{d b}+0.29 T_{w b}
$$

where:

$\mathrm{THI}_{5-6 \mathrm{wk}}$ - temperature-humidity index for the $5^{\text {th }}$ and $6^{\text {th }}$ week of fattening $\left({ }^{\circ} \mathrm{C}\right)$

$T_{d b} \quad-$ dry-bulb temperature $\left({ }^{\circ} \mathrm{C}\right)$

$T_{w b} \quad$ - wet-bulb temperature $\left({ }^{\circ} \mathrm{C}\right)$

During both periods $L 1$ and $L 2$ in the hall 3 , the temperature of the straw bed and surface temperature of the concrete floor under the straw bedding were measured using the DS 80 temperature datalogger at intervals of 10 minutes. Mortality and climatic parameters were evaluated statistically during each fattening period using STATISTICA 10 software. For this purpose, fattening periods were divided into 3 equal phases: $P 1$ phase - from day 1 to day $13 ; P 2$ phase - from day 14 to day 26; $P 3$ phase - from day 27 to day 39.

Differences between halls and between individual periods in terms of mortality and climatic factors were evaluated by a Multifactor ANOVA; difference significance was determined by Sheffe's test.

\section{Results and discussion}

\section{Mortality during fattening period}

Total mortality during $L 1$ at entire farm was 4,369 birds, representing $4.28 \%$ of total number of birds at farm. Daily mortality rate during $L 1$ varied from 5 to 702 birds per hall (Fig. 2). During the first fattening week, it was from 6 to 49 birds. Total mortality during whole first week was 121 birds per hall, representing $0.72 \%$ of the total number of birds. This is in range of $0-3.3 \%$ reported by Yassin et al. (2009). Mortality observed during the first fattening week was also lower than the values of Heier et al. (2002), who evaluated mortality at the beginning of fattening period at different times of the year (1.05\% for June).

Average mortality rate during $P 1$ phase ( $1^{\text {st }}$ to $13^{\text {th }}$ day) was 15.31 birds per day and per hall. During $P 2$ phase $\left(14^{\text {th }}\right.$ to $26^{\text {th }}$ day), daily mortality was very low and balanced, ranging from 5 to 10 birds per day and per hall; average mortality rate was 7.73 birds per day and per hall. During $P 3$ phase $\left(27^{\text {th }}\right.$ to $39^{\text {th }}$ day), daily records continued to show the trend of low mortality with the exception of the $31^{\text {st }}$ day, when chicken mortality increased acutely and ranged in individual halls from 148 to 702 . After this event, mortality was low again as during $P 2$ until day 39 , i.e. until the end of

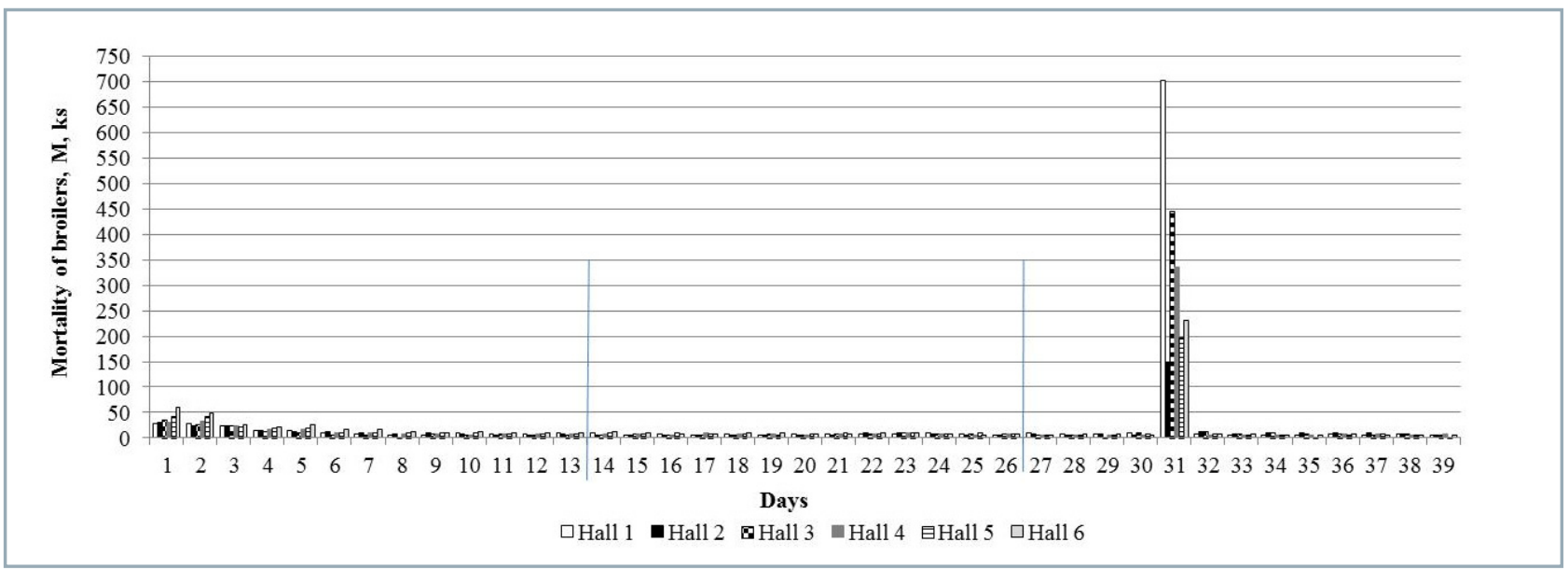

Fig. 2 Daily mortality of broilers in 6 halls during the summer fattening period $L 1$

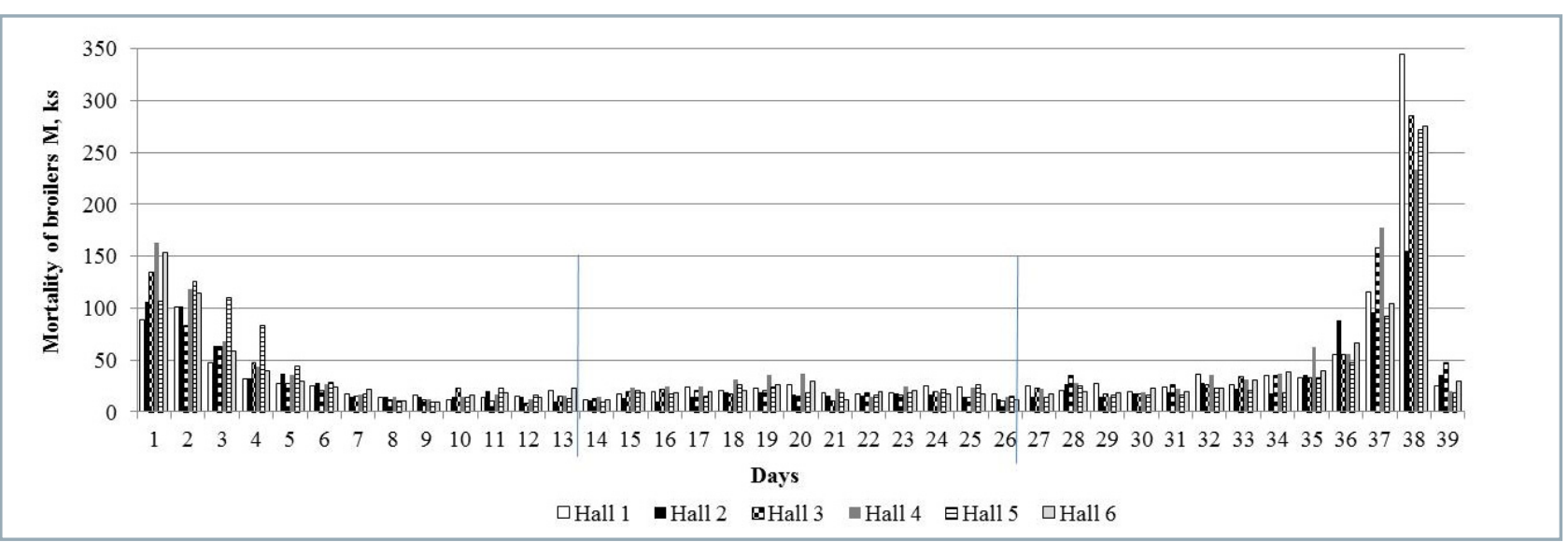

Fig. 3 Daily mortality of broilers in 6 halls during $L 2$ 
Table 1 Results of Multifactor ANOVA of mortality differences among 6 halls and 3 phases of $L 1$

\begin{tabular}{|l||c|c|c|c|c|c|}
\hline \multicolumn{1}{|c|}{} & SS & df & MS & F & P-value & F crit \\
\hline Halls* & $60,350.9$ & 5 & $12,070.2$ & 0.7346 & 0.6141 & 3.32583 \\
\hline Phases** & 340,285 & 2 & 170,142 & 10.355 & 0.00366 & 4.10282 \\
\hline Error & 164,310 & 10 & 16,431 & & \\
\hline Total & 564,946 & 17 & & & \\
\hline
\end{tabular}

Table 2 Results of Multifactor ANOVA of mortality differences among 6 halls and 3 phases of $L 2$

\begin{tabular}{|c|c|c|c|c|c|c|}
\hline \multicolumn{7}{|c|}{ ANOVA } \\
\hline & ss & $d f$ & MS & $F$ & $P$-value & $F$ crit \\
\hline Halls* & $25,783.6$ & 5 & $5,156.72$ & 1.11118 & 0.41305 & 3.32583 \\
\hline Phases** & 642,990 & 2 & 321,495 & 69.2764 & $1.4 \mathrm{E}-06$ & 4.10282 \\
\hline Error & $46,407.6$ & 10 & $4,640.76$ & & & \\
\hline Total & 715,181 & 17 & & & & \\
\hline
\end{tabular}

the fattening period. Average mortality rate during $P 3$ phase was 32.97 birds per day and per hall.

A statistical comparison showed that the total mortality during $P 3$ phase was significantly higher $\left(P_{L 1}=0.0036\right)$ than mortality during $P 1$ and $P 2$ phases (Tab. 1). The differences between the halls were statistically insignificant $(P=0.614)$.

Total mortality during $L 2$ at entire farm was 8,783 birds, representing $8.66 \%$ of total number of birds at farm. It was more than twice as high as during $L 1$. Daily mortality rate during $L 2$ varied from 10 to 155 birds per hall (Fig. 3). Daily mortality during period $L 2$ in individual halls during the first fattening week ranged from 16 to 163 birds per day and per hall, which was then reduced to an average daily mortality rate of 10 to 19 birds per day and per hall. Total mortality during the entire first week was 377 birds per hall, representing $2.22 \%$ of total number of birds per hall. It is more than in $L 1$; however, it is still in the range of $0-3.3 \%$ reported by Yassin et al. (2009) for first 7 days. In comparison with the results of Heier et al. (2002), we observed higher mortality.

The average death rate for the phase $P 1$ was 39.42 birds per day and per hall. In the phase $P 2$ it was 18.99 birds per day and per hall. During $P 3$ phase, daily mortality ranged from 14 to 345 birds per day and per hall with higher mortality during the last week of the batch. Average mortality rate during $P 3$ phase was 54.32 birds per day and per hall. Furthermore, total mortality during $P 3$ phase was significantly higher than the mortality during $P 1$ and $P 2$ phases $\left(P_{L 2}=1.4 \cdot 10^{-6}\right)$ during this fattening period and differences between the halls were statistically insignificant $(P=0.413)$, (Tab. 2).

\section{Average daily microclimatic parameters}

As no bacteriological infections or diseases have occurred at the farm during the observed periods, it is assumed

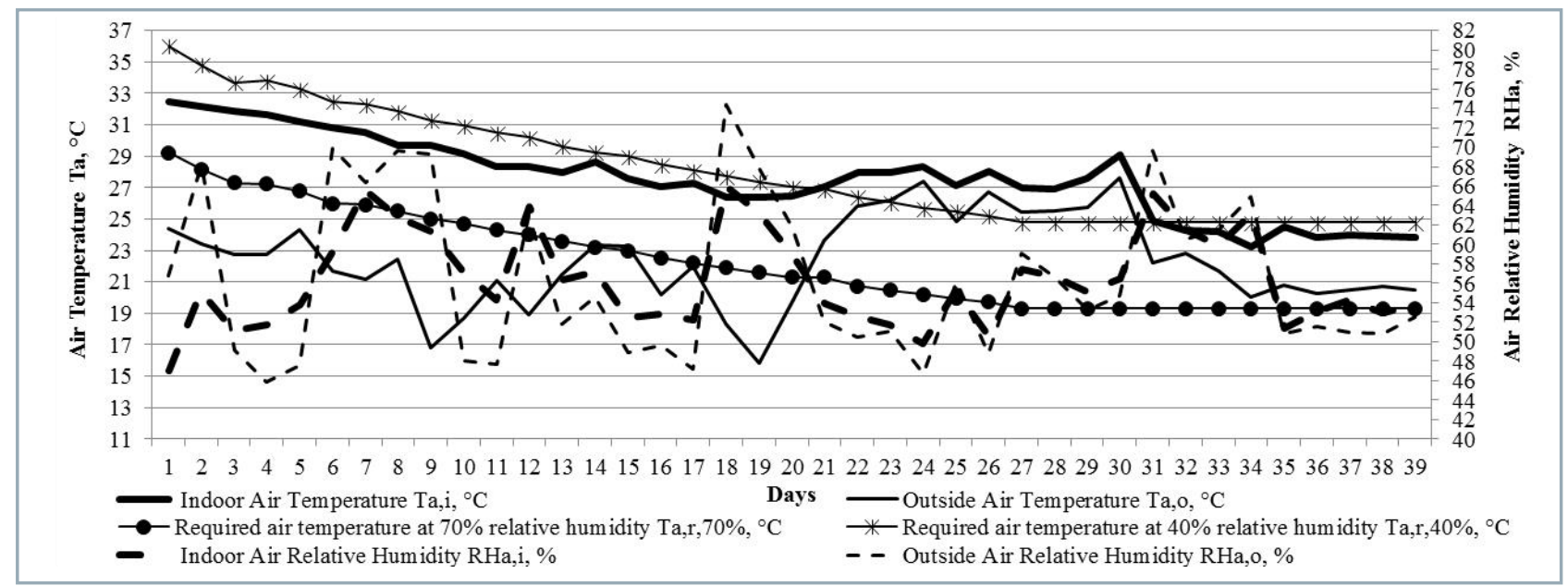

Fig. 4 Daily average indoor and outdoor microclimate parameters during summer for $L 1$ 


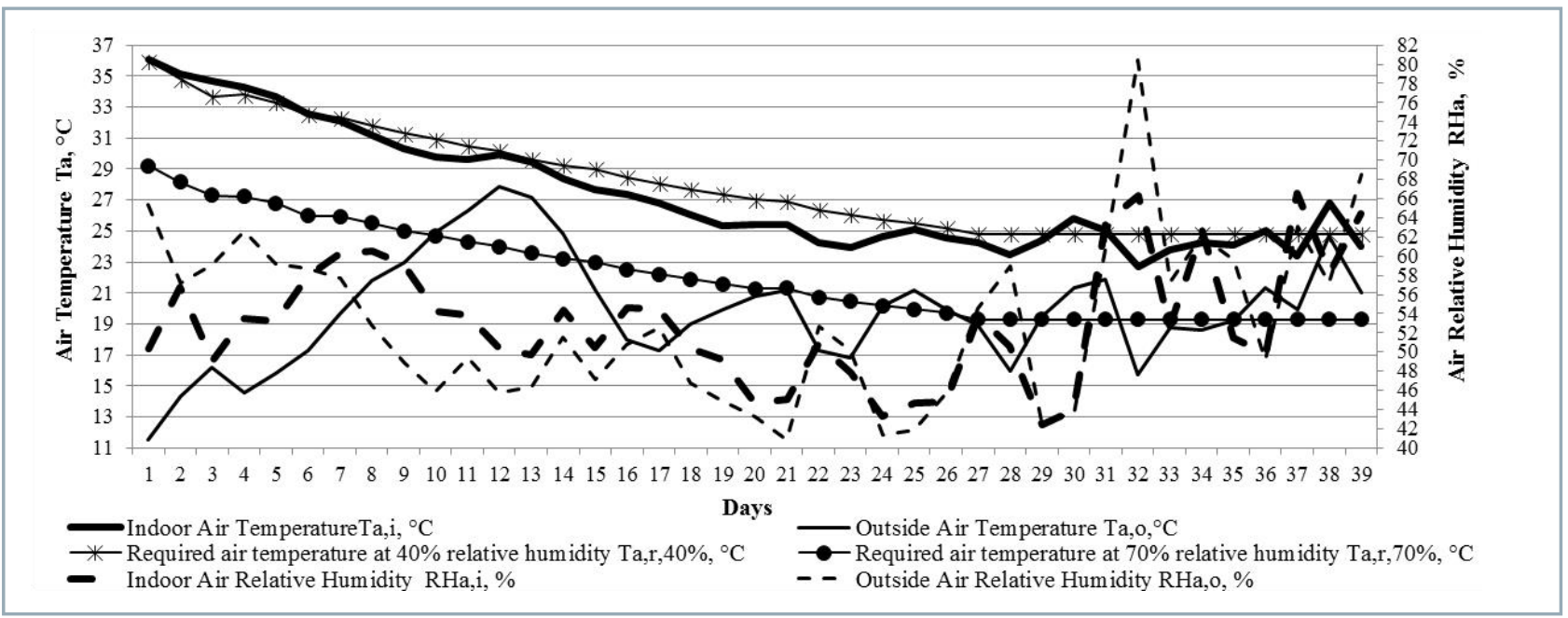

Fig. 5 Daily average indoor and outdoor microclimate parameters during summer for $L 2$

that the increase in mortality is caused by changes in the temperature and humidity of the environment during summer. This is in compliance with studies by Teeter et al. (1985), Macari and Furlan (2001), Tao and Xin (2003), Chepete et al. (2005) and Jones et al. (2005), who have showed an importance of average daily temperature in predicting high broiler mortality due to heat stress. Another related study (Li et al., 2000) presented that broiler chickens exposed to heat load will also reduce the daily feed intake. Temperature and relative humidity of the indoor and outdoor air during $L 1$ and $L 2$ are shown in Figs. 4 and 5, respectively. Average daily indoor air temperatures were higher than outdoor air temperatures during all days of both summer periods. Indoor daily temperature values were almost always going down during $L 1$ from $32.4^{\circ} \mathrm{C}$ to $23.8^{\circ} \mathrm{C}$ and from $36.1{ }^{\circ} \mathrm{C}$ to $24.1^{\circ} \mathrm{C}$ during $L 2$, as the chickens were getting older. However, these were almost always higher than results shown by Vale et al. (2008), who connected the average daily temperature exceeding $24^{\circ} \mathrm{C}$ with poor ventilation $\left(\mathrm{v} \leq 1.4 \mathrm{~m} \cdot \mathrm{s}^{-1}\right)$ with and high mortality rate of broiler chickens.

Average daily temperatures during $L 1$ went beyond the recommended temperatures set for critical $R H=40 \%$ from $21^{\text {st }}$ to $31^{\text {st }}$ day. During $L 2$, it was from $29^{\text {th }}$ to $31^{\text {st }}$ day and from $36^{\text {th }}$ to $38^{\text {th }}$ day of fattening period. Especially high mortality occurred during $L 1$ on $31^{\text {st }}$ day and on $36^{\text {th }}, 37^{\text {th }}, 38^{\text {th }}$ days during $L 2$. Average outdoor air temperature fluctuated with the minimum temperatures of $T_{a, 0, m i n, L 1}=15.8^{\circ} \mathrm{C}$ during $\angle 1$ period, and of $T_{a, 0, \min , L 2}=11.5^{\circ} \mathrm{C}$ during $L 2$ and with the maximum temperatures of $T_{a, 0, \max , L 1}=27.6{ }^{\circ} \mathrm{C}$ during $L 1$, and of $T_{a, 0, \text { max } L 22}=27.9{ }^{\circ} \mathrm{C}$ during $L 2$. Temperature-humidity index during $L 1 \mathrm{THI}_{d 30}=27.12^{\circ} \mathrm{C}$ exceeded the critical value of $\mathrm{THI}_{\text {crit }} \geq 23^{\circ} \mathrm{C}$ published by Vale et al. (2010). THI during L2 was slightly lower than $23^{\circ} \mathrm{C}$. On the three most critical days of $P 3$ phase, $T H I$ values were $\mathrm{THI}_{36}=22.72{ }^{\circ} \mathrm{C}, \mathrm{THI}_{37}=$ $22.03{ }^{\circ} \mathrm{C}$ and $\mathrm{THI}_{38}=22.09{ }^{\circ} \mathrm{C}$ even though the mortality increased to 155 birds $\left(M_{d 36}=88, M_{d 37}=96, M_{d 38}=155\right)$. In both cases of evaluated fattening period, average values of daily temperature and relative humidity were not consistent with the occurrence of death. Atmospheric influx of outdoor hot waves during $L 1$ (from $22^{\text {nd }}$ to $31^{\text {st }}$ day) and during $L 2$ period $\left(29^{\text {th }}\right.$ to $31^{\text {st }}$ day and $36^{\text {th }}$ to $38^{\text {th }}$ day) were certainly unbearable for animals, yet this was not shown in mortality. We believe that, for this purpose, it would be more evident to use so-called differential temperatures $\Delta T_{v}$, i.e. values by which the temperature values recommended on the basis of $R H$ have been exceeded.

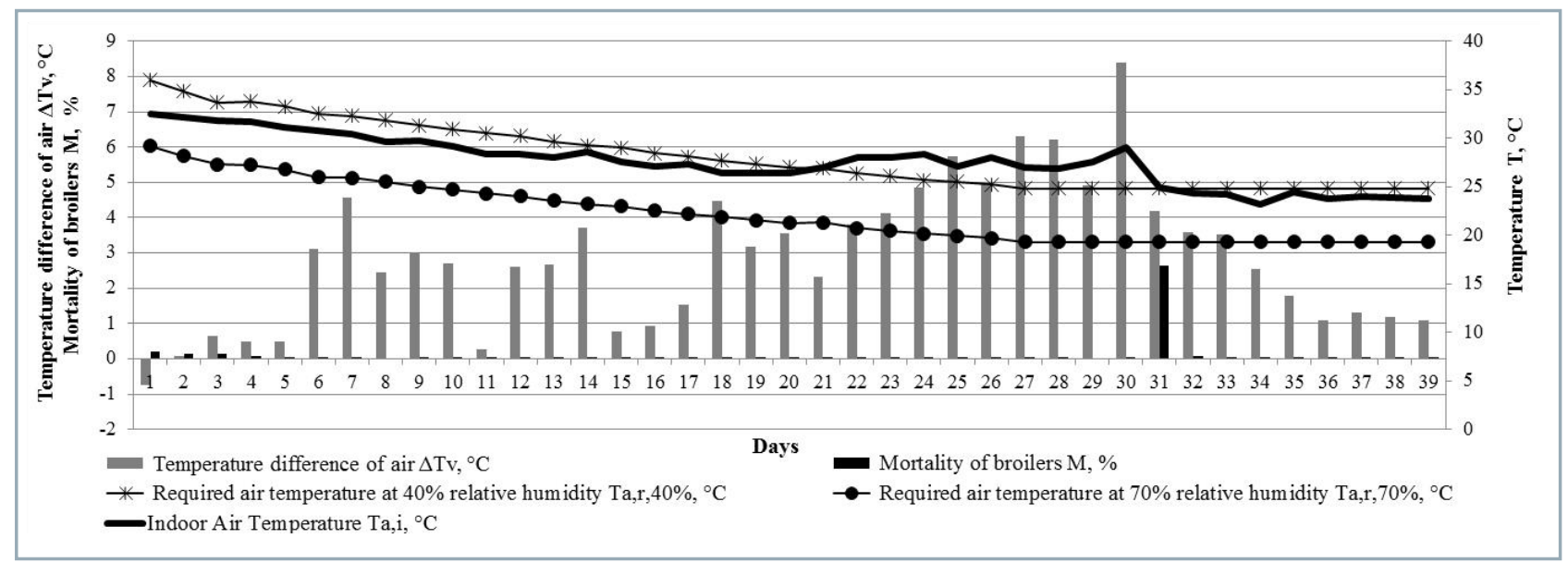

Fig. 6 Daily temperature differences $\Delta T$, daily mortality $M_{d 1-d 39}$ and average daily air temperature $T_{a i}$ in Hall 3 during $L 1$ 


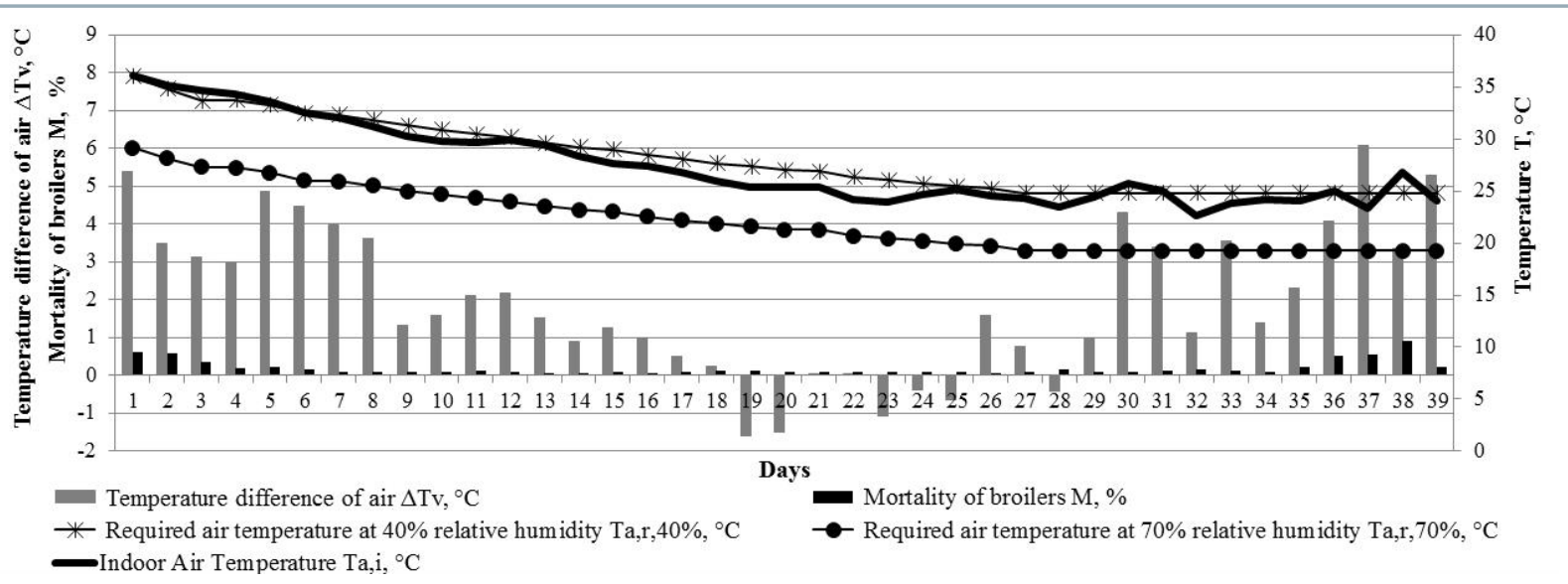

Fig. 7 Daily temperature differences $\Delta T_{v^{\prime}}$ daily mortality $M_{d 1-d 39}$ and average daily air temperature $T_{a i}$ in Hall 3 during $L 2$

\section{Differential temperatures}

Resulting temperature differences between the actual measured and recommended temperatures during $L 1$ and $L 2$ are shown in Figs. 6, respectively. There is shown the percentage of dead animals occurred in Hall 3 on each day. Positive temperature differences during both fattening periods are more sensitive to the animal mortality trend, as they also take into account the relative humidity status of each day. At $30^{\text {th }}$ day $L 1$, the highest indoor temperature difference was recorded $\Delta T_{v, d 30}=8.4^{\circ} \mathrm{C}$, followed by a large increase in mortality $M_{d 31}=447$. During $L 2$, heat spike began earlier, on $29^{\text {th }}$ day. There was also a sudden exceedance of the recommended temperature range at $30^{\text {th }}$ and $31^{\text {th }}$ day $\left(\Delta T_{v, d 30}=4.3^{\circ} \mathrm{C} ; \Delta T_{v, d 31}=3.4^{\circ} \mathrm{C}\right)$, however, mortality did not increase. On $36^{\text {th }}$ and $37^{\text {th }}$ days, $\Delta T_{v}$ suddenly increased again with increase in mortality. The highest animal mortality occurred on $38^{\text {th }}$ day of chickens fattening, which, if disease excluded, could be associated with an increase in indoor air temperature differences $\Delta T_{v, d 36}=4.1^{\circ} \mathrm{C} ; \Delta T_{v, d 37}=6.1^{\circ} \mathrm{C}$.

Although the differential temperature assessment was more accurate than average daily temperatures, it was observed that animals were able to adapt to microclimatic conditions and no increase in mortality was recorded at $\Delta T_{v, d 27}=6.3^{\circ} \mathrm{C}$ and $\Delta T_{v, d 28}=6.2^{\circ} \mathrm{C}$ during L1. On the other hand, acute deaths occurs under less demanding conditions at $\Delta T_{v, d 36}=4.1^{\circ} \mathrm{C}$ and $\Delta T_{v, d 37}=6.1^{\circ} \mathrm{C}$ during $L 2$. Solution to this issue could lie in analysis of more critical days at shorter intervals.

\section{Evaluation of critical days through average hourly microclimate parameters}

It was observed that during the $30^{\text {th }}$ and $31^{\text {st }}$ day of the fattening period $L 1$ with average daily indoor temperatures $29.1^{\circ} \mathrm{C}$ and $24.9^{\circ} \mathrm{C}$, there was hourly recorded temperature higher than $30^{\circ} \mathrm{C}$ for more than 10 hours (from 9:50 to 20:00) (Fig. 8). In afternoon of $30^{\text {th }}$ day, temperature exceeded $32^{\circ} \mathrm{C}$ from 11:00 AM to 6:00 PM and it exceeded $34{ }^{\circ} \mathrm{C}$ for more than 2 hours. On $31^{\text {st }}$ day of same fattening period with average daily relative humidity of $65.2 \%$, hourly relative humidity exceeded 70\% for more than 6 hours (from 1:00 to 7:20). Such conditions caused the highest animal mortality in the entire fattening period ( 447 birds, in individual halls the mortality ranged from 248 to 702 birds). This is in compliance with results of previous studies reporting that a temperature of $32{ }^{\circ} \mathrm{C}$ (Cooper and Washburn, 1998) is unbearable for chickens.

On the basis of average hourly analysis of data from L2, it is possible to conclude that none of internal air temperatures exceeded $30{ }^{\circ} \mathrm{C}$ (Fig. 9) on $35^{\text {th }}$ and $36^{\text {th }}$ days, but animal mortality was higher than in $L 1$. Average daily

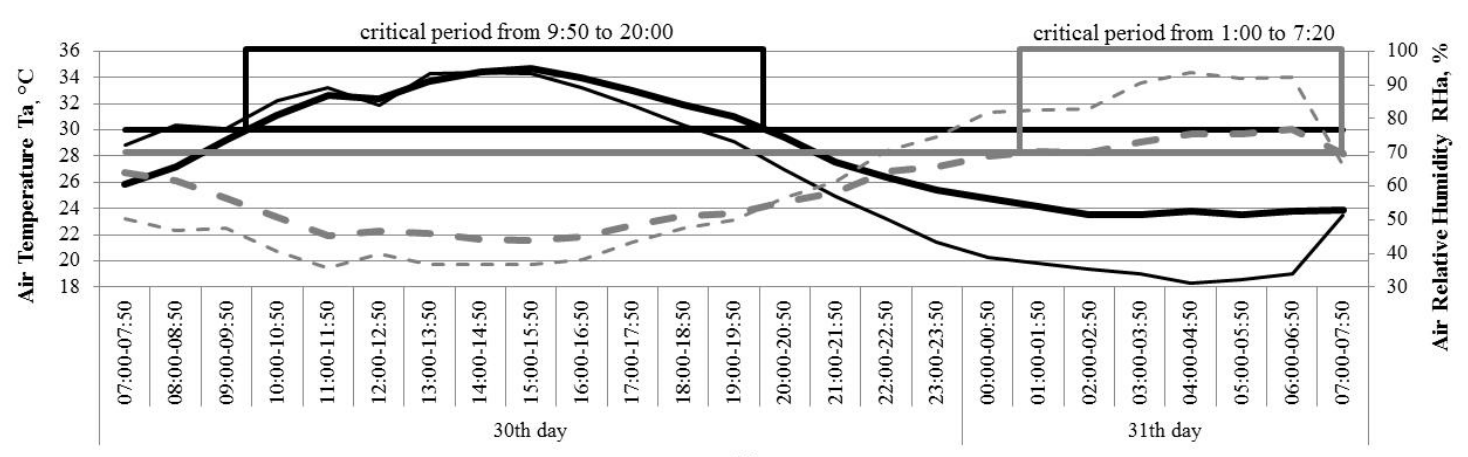

Time

— Outside Air Temperature Ta,o, ${ }^{\circ} \mathrm{C} \quad$ Indoor Air Temperature Ta, $\mathrm{i},{ }^{\circ} \mathrm{C} \quad$ Critical Air Temperature Ta,crit, ${ }^{\circ} \mathrm{C}$

- - Outside Air Relative Humidity RHa,o, \% - Indoor Air Relative Humidity RHa,i, \% — Critical Air Relative Humidity RHa,crit, \%

Fig. 8 Average hourly microclimate data during critical $30^{\text {th }}$ day of $L 1$, followed by very high acute chicken mortality 


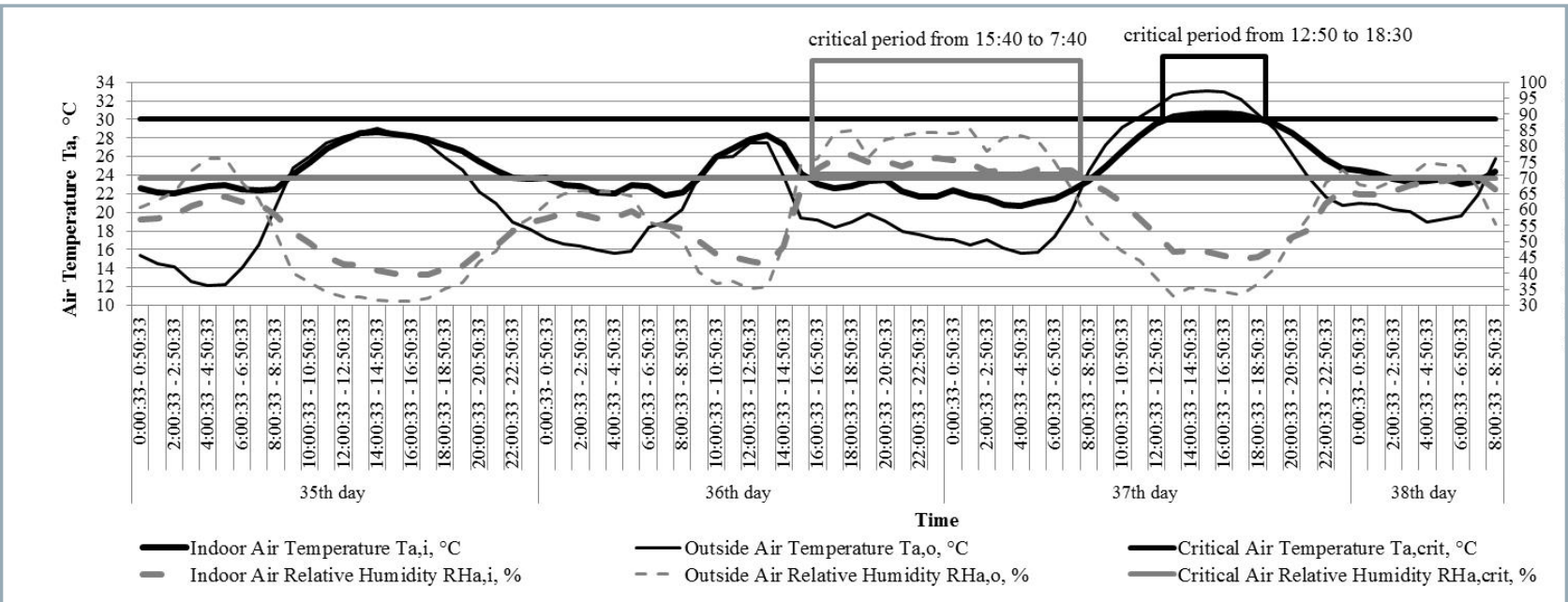

Fig. 9 Average hourly microclimate parameter data during critical time of $L 2$

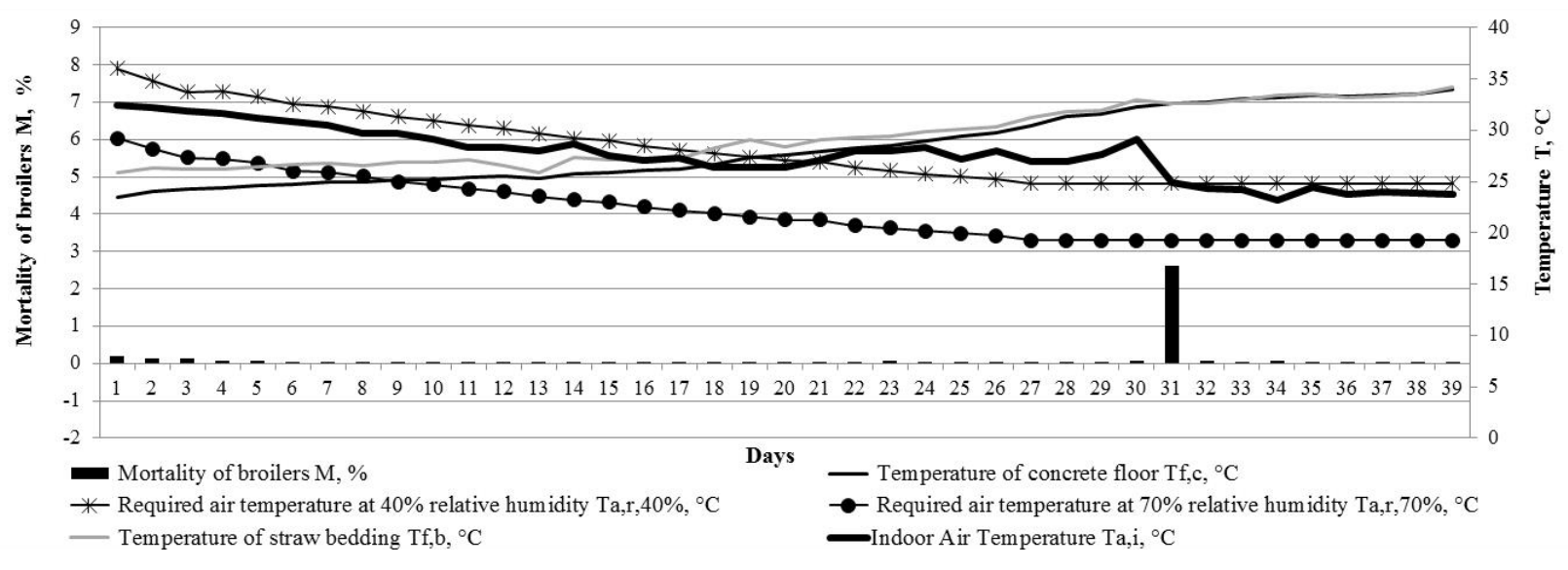

Fig. 10 Results of continuous measurements of temperature of straw bed $T_{f, b}$ and concrete surface temperature $T_{f, c}$ during $L 1$ and their comparison to average daily indoor air temperature and required temperature

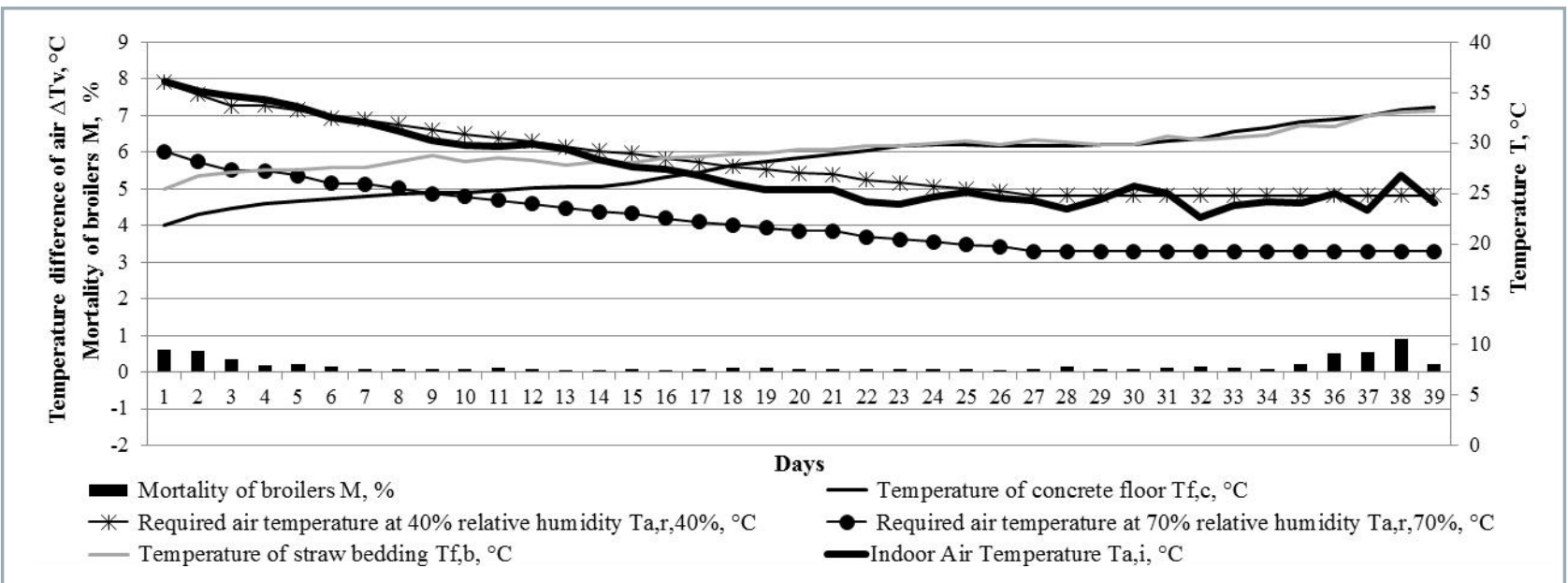

Fig. 11 Results of continuous measurements of concrete surface temperature $T_{f, c}$ and temperature of bed $T_{f, b}$ during $L 2$ and their comparison to average daily indoor air temperature and required temperature 
indoor air temperature on $35^{\text {th }}$ day was $24.1^{\circ} \mathrm{C}$ and it was $25.0^{\circ} \mathrm{C}$ on $36^{\text {th }}$ day. However, an increase in the differential temperature $\Delta T_{v}$ began to occur already since the $35^{\text {th }}$ day and it reached $\Delta T_{v, d 36}=4.2^{\circ} \mathrm{C}$ on $36^{\text {th }}$ day and was already $\Delta T_{v, d 37}=6.2^{\circ} \mathrm{C}$ on $37^{\text {th }}$ day. This influence is considered to be significant in relation to high daily mortality on $36^{\text {th }}$, $37^{\text {th }}$ and $38^{\text {th }}$ days of $L 2\left(M_{d 36}=88\right.$ birds, $M_{d 37}=96$ birds, $M_{d 38}=155$ birds). Simultaneously, we found that during the night before the day of major mortality occurred (36/37 days), relative humidity exceeded $70 \%$ for 16 hours (from 15:40 to 7:40), what certainly contributed to increased mortality on $37^{\text {th }}$ day. On $37^{\text {th }}$ day of $L 2$, critical indoor air temperature exceeded $30{ }^{\circ} \mathrm{C}$ for more than 5 hours (from $12: 50$ to $18: 30)$. Continuous high temperature on $38^{\text {th }}$ day for 4 hours (15:00 to 18:50) and relative humidity exceeding $70 \%(6: 00$ to $7: 50)$ resulted in the highest mortality during $L 2\left(M_{d 38}=155\right.$ birds).

\section{Floor temperature}

On the basis of results from continuous measurements of straw bed temperature during $L 1$, it was found that average daily temperature of straw was gradually increasing from the initial temperature of $T_{f, b, d 1}=25.85^{\circ} \mathrm{C}$ to the final value of $T_{f, b, d 39}=34.18^{\circ} \mathrm{C}$ (Fig. 10). Similarly, surface temperature of concrete floor under the straw bedding showed increasing trend (from $T_{f, c, d 1}=23.52{ }^{\circ} \mathrm{C}$ to $T_{f, c, d 39}=34.01{ }^{\circ} \mathrm{C}$ ). During period since $18^{\text {th }}$ to final day of $L_{2}$, it was found that temperatures of concrete floor and straw bed exceeded recommended ambient temperature and were constantly increasing (min. increase of $\Delta T_{f, c, 40 \%}=9.2{ }^{\circ} \mathrm{C}$ and max. increase $\Delta T_{f, c 70 \%}=14.7^{\circ} \mathrm{C}$ ). Floor with temperature higher than desired animal ambient temperature (Ross, 2018) at the end of fattening period would certainly not reduce the heat load of birds. Due to warm concrete floors, emitting bedding materials and metabolic heat produced by animals at the end of the fattening period, approximately the same average daily temperature straw $\left(34.18^{\circ} \mathrm{C}\right)$ was reached as in case of concrete floor $\left(34.01{ }^{\circ} \mathrm{C}\right)$. This phenomenon can dangerously contribute to overheating the animals just in the last days of fattening when animals lie on floor for longer time and time of potential conductive share of the form of heat transfer between the body and pad decreases.

Furthermore, temperatures of straw bed concrete floor surface were gradually increasing from $T_{f, b, d 1}=25.49{ }^{\circ} \mathrm{C}$ to $T_{f, b, d 39}=33.2^{\circ} \mathrm{C}$ and from $T_{f, c, d 1}=21.81{ }^{\circ} \mathrm{C}$ to $T_{f, c, d 39}=33.5^{\circ} \mathrm{C}$ during $L 2$ (Fig. 11). Since $19^{\text {th }}$ day, both temperatures exceeded the recommended air temperature range; on $39^{\text {th }}$ day of fattening period, temperature of the concrete floor reached a significant increase above the required air temperatures $\left(\Delta T_{f, c, 40 \%}=8.7^{\circ} \mathrm{C}\right.$ and $\left.\Delta T_{f, c, 70 \%}=14.2^{\circ} \mathrm{C}\right)$.

\section{Conclusions}

Mortality of chickens during two summer fattening periods in thermally insulated halls frequently used for chicken fattening in Slovakia with a final ventilation intensity of more than 10 cubic meters per hour per bird was evaluated. Effect of microclimatic conditions in housing area on recorded mortality was analysed. Following conclusions can be drawn considering the measurements and analyses:

- Increased mortality occurred at the beginning of fattening periods; however, an acute increase of mortality caused by summer heat spikes occurred when chickens were older than 27 days. The hypothesis $\mathrm{H} 1$ was confirmed.

- Mortality did not occur even when average daily temperature exceeded the recommended temperature range. Higher mortality occurred only when differential temperatures were observed to be rising, values of which took into account the relative humidity. Increased mortality generally occurred when differential temperature values were higher than $8{ }^{\circ} \mathrm{C}$. Hypothesis $\mathrm{H} 2$ was disproved and hypothesis $\mathrm{H} 3$ was confirmed.

- There was rarely a situation when the differential temperature did not exceeded $8{ }^{\circ} \mathrm{C}$ yet occurrence of increased mortality was recorded. This required a detailed analysis of that day. Detailed (hour and minute) microclimate parameter record showed that there were uninterrupted extended time periods ( 6 hours or more) within 24 hours when the average hourly temperature exceeded $30^{\circ} \mathrm{C}$ and/or the relative air humidity exceeded $70 \%$. The hypothesis $\mathrm{H} 4$ was confirmed.

- Temperatures of straw bed and concrete floor surface were gradually increasing during both fattening periods up to $34{ }^{\circ} \mathrm{C}$ without any significant fluctuation during particular days. Required air temperatures were exceeded since $19^{\text {th }}$ day. High temperatures of straw bed and concrete floor, together with high temperatures and high relative humidity, contributed to increased mortality during critical days. The hypothesis $\mathrm{H} 5$ was disproved.

- The $T H /$ value on critical day of mortality incidence during $L 1$ fattening period was much higher than commonly used critical value. On each of critical days during $L 2$, it was slightly lower than $23^{\circ} \mathrm{C}$. Due to this reason, it can be recommended to decrease the critical value to $22^{\circ} \mathrm{C}$.

We have documented that high occurrence of mortality in summer during the last phase of broiler fattening period due to sudden hot weather waves. To detect and eliminate their effects, it is not enough to monitor only average daily temperatures. It is necessary to use more detailed methods, as presented in this paper, i.e. differential temperatures and/or temperature and $R H$ analysis at hourly intervals at minimum. This will provide possibility to use modern technologies effectively for microclimate regulation in housing (heat pumps, water fog, floor cooling, etc.) with their digitized control supported by a data obtained from detailed analysis.

\section{References}

ALGERS, B. - BERG, C. 2001. Monitoring animal welfare on commercial broiler farms in Sweden. In Acta Agriculturae Scandinavica, Section A - Animal Science, vol. 30, pp. 88-92.

BANSAL, V. - MISHRA, R. - AGARWAL, G. - MATHUR, J. 2012. Performance analysis of integrated earth-air-tunnel-evaporative cooling system in hot and dry climate. In Energy and Buildings, 2012, vol. 47, pp. 525-532.

BOĎO, Š. - GÁLIK, R. 2018. Monitoring of litter quality and temperature in breeding of fattening chickens. In Acta Technologica Agriculturae, vol. 21, no. 1, pp. 33-37.

COOPER, M. A. - WASHBURN, K. W. 1998. The relationships of body temperature to weight gain, feed consumption, and feed utilization in broilers under heat stress. In Poultry Science, vol. 77, pp. 237-242. 
CORDEIRO, M. B. - TINÔCO, I. F. F. - MESQUITA, F. R. M. - SOUSA F. C. 2011. Análise de imagens digitais para a avaliação do comportamento de pintainhos de corte. In Engenharia Agrícola, vol. 31, pp. 418-426.

CZARICK, M. - FAIRCHILD, B. 2012. Relative humidity... The best measure of overall poultry house air quality. In Poultry Housing Tips, vol. 24, no. 2, pp. 1-3.

GENC, L. - PORTIER, K. 2003. Sensible and latent heat productions from broilers in laboratory conditions. In Turkish Journal of Veterinary and Animal Sciences, vol. 29, pp. 635-643.

HALL, A. L. 2001. The effect of stocking density on the welfare and behaviour of broiler chickens reared commercially. In Animal Welfare, vol. 10, pp. 23-40.

HEIER, B. T. - HOGASEN, H. R. - JARP, J. 2002. Factors associated with mortality in Norwegian broiler flocks. In Preventive Veterinary Medicine, vol. 53, pp. $147-157$.

CHEPETE, H. J. - CHIMBOMBI, E. - TSHEKO, R. 2005. Production performance and temperature-humidity index of COBB 500 broilers reared in open-sided naturally ventilated houses in Botswana. In Livestock Environment - international symposium 7, pp. 524-535.

CHOU, C. C. - JIANG, D. D. - HUNG, Y. P. 2004. Risk factors for cumulative mortality in broiler chicken flocks in the first week of life in Taiwan. In Brazilian Journal of Poultry Science, vol. 45, pp. 573-577.

JONES, T. A. - DONNELLY, C. A. - STAMP, D. M. 2005. Environmental and management factors affecting the welfare of chickens on commercial farms in the United Kingdom and Denmark stocked at five densities. In Poultry Science, vol. 84, pp. 1155-1165.

KOCAMAN, B. - YAGANOGLU, A. V. - YANAR, M. 2005. Combination of fan ventilation system and spraying of oil-water mixture on the levels of dust and gases in caged layer facilities in Eastern Turkey. In Journal of Applied Animal Research, vol. 27, pp. 109-111.

LI, S. Y. - ZHANG, M. H. - ZHANG, Z. Y. - YAN, S. - DU, R. - WANG, K. L. 2000. Effect of heat stress on performance of broilers and some blood biological and endocrinological variate. In Acta Agricuturae Boreali-Sinica, vol. 15, no. 3, pp. 140-144.

LIANG, Y. - XIN, H. - LI, H. - WHEELER, E. F. - ZAJACZKOWSKI, J. L. - TOPPER, P. A. - GATES, R. S. - CASEY, K. D. - BEHRENDS, B. B. - BURNHAM, D. J. - ZAJACZKOWSKI, F. J. 2005. Ammonia emissions from U. S. laying hen houses in lowa and Pennsylvania. In Transactions of the ASAE, vol. 48, no. 5, pp. 1927-1941.

LIN, H. - JIAO, H. C. - BUYSE, J. - DECUYPERE, E. 2006. Strategies for prevent heat stress in poultry. In Poultry Science Journal, vol. 62, pp. 71-85.

MACARI, M. - FURLAN, R. L. 2001. Environment science on poultry production under tropical climate. In SILVA, I.J.O. (Ed). Environmental science on poultry production under tropical climate. Piracicaba: FUNEP, 2001, pp. 146-164.
NAWALANY, G. - BIEDA, W. - RADON, J. 2010. Effect of floor heating and cooling of bedding on thermal conditions in the living area of broiler chickens. In Archiv fur Geflugelkunde, vol. 74, no. 2, pp. 98-101.

NAWALANY, G. 2012. A proposal to apply operative temperature for the evaluation of thermal conditions in the broiler living zone. In Archiv fur Geflugelkunde, vol. 76, no 1, pp. 49-54.

OKELO, P. O. - CARR, L. E. - HARRISON, P. C. - DOUGLASS, L. W. BYRD, V. E. - WABECK, S. W. 2003. Effectivenes of a novel method to reduce heat stress in broilers: A cool roost system. In Transactions of the ASAE, vol. 46, no. 6, pp. 1675-1683.

ROSS Broiler Management Handbook 2018. Aviagen 2018. pp. 1-148.

SAX, M. - CAENEGEM, L. - SCHICK, M. 2012. Optimales stallklima dank wärmerückgewinnungsanlagen auch im sommer. In Agrarforschung Schweiz, vol. 3, no. 9, pp. 428-435.

SORENSEN, P. - SU, G. - KESTIN, S. C. 2000. Effects of age and stocking density on leg weakness in broiler chickens. In Poultry Science, vol. 79, pp. 864-870.

TAO, X. - XIN, H. 2003. Temperature-humidity-velocity index for market-size broilers. In Transactions of the ASAE, Paper N 034037, Nevada, 2003, pp. 1-12.

TEETER, R. G. - SMITH, M. O. - OWENS, F. N. - ARP, S. C. - SANGIAH, S. - BREAZILE, E. 1985. Chronic heat stress and respiratory alkalosis: occurrence and treatment in broiler chicks. In Poultry Science, vol. 64, pp. 1060-1064.

THIELE, H. H. - POTTGÜTER, R. 2008. Management recommendations for laying hens in deep litter, perchery and free range systems. In Lohmman Information, vol. 43, pp. 53-63.

VALE, M. M. - MOURA, D. J. - NÄÄS, I. A. - OLIVEIRA, S. R. M. RODRIGUES, L. H. A. 2008. Data mining to estimate broiler mortality when exposed to heat wave. In Scientia Agricola, vol. 65, no. 3, pp. 223-229.

VALE, M. M. - MOURA, D. J. - NÄÄS, I. A. - PEREIRA, D. F. 2010. Characterization of heat waves affecting mortality rates of broilers between 29 days and market age. In Brazilian Journal of Poultry Science, vol. 12, no. 4, pp. 279-285.

XIN, H. - BERRY, I. - TABLER, G. T. - COSTELLO, T. 2001. Heat moisture production of poultry and their housing systems: Broilers. In Transaction of the ASAE. Agricultural and Biosystems Engineering, vol. 44, no. 6, pp. 1851-1857.

YASSIN, H. - VELTHUIS, A. G. J. - BOERJAN, M. - RIEL, J. 2009. Field study on broilers' first-week mortality. In Poultry Science, vol. 88, pp. 798-804. 